ERRATUM

\title{
Molecular characterization of Cystoisospora belli and unizoite tissue cyst in patients with Acquired Immunodeficiency Syndrome - ERRATUM
}

JORGE NÉSTOR VELÁSQUEZ, GERMÁN ASTUDILLO OSVALDO, CECILIA DI RISIO, CRISTINA ETCHART, AGUSTÍN VÍCTOR CHERTCOFF, GLADYS ELISABET PERISSÉ and SILVANA CARNEVALE

doi:10.1017/S0031182010001253, Published by Cambridge University Press 9 September 2010.

The second author's name should have been written as Osvaldo Germán Astudillo.

REFERENCE

Velasquez, J. N. et al. (2010). Molecular characterization of Cystoisospora belli and unizoite tissue cyst in patients with Acquired Immunodeficiency Syndrome. Parasitology Published by Cambridge University Press, 9 September 2010. doi: 10.1017/S0031182010001253. 